\title{
Impacts of experimental drought on community structure and floristic composition of tree saplings in a lowland tropical rainforest in Eastern Amazonia \\ Impacto da seca artificial na estrutura e na florística da comunidade de plantas em uma floresta tropical na Amazônia oriental
}

\author{
Leandro Valle Ferreira', Denise de Andrade Cunha', Pia Parolin", Antônio Carlos Lôla da Costa'II \\ 'Museu Paraense Emílio Goeldi/MCTIC. Belém, Pará, Brasil \\ "Institut National de la Recherche Agronomique. Paris, França \\ "'Universidade Federal do Pará. Belém, Pará, Brasil
}

\begin{abstract}
In order to test the effect of the lower availability of water for vegetation in a tropical Amazonian forest, a long-term research project was created in 2001 called Projeto Seca Floresta (ESECAFLOR). The main objective of the project is to determine how a significant reduction of the available water in the soil, in the long term, can affect the biota. The ESECAFLOR consists of two 1-hectare plots, the experimental plot is covered with 6,000 plastic panels reducing precipitation by $50 \%$. The objective of this work is to compare the floristic and plant structure ( $<2$ meters high) between the experimental and control of ESECAFLOR plots. There was a significant reduction in species richness and diversity, plant density and height, and a significant change in species composition between experimental plot compared to control. The plant community clearly responded to the reduction of soil moisture in the experimental plot, corroborating the results of some climate models that say rainfall reduction in the Amazon will negatively affect the plant community.
\end{abstract}

Keywords: Drought effects. Soil water availability. Tree sapling community. Amazon rainforest.

Resumo: Para testar o efeito da menor disponibilidade de água para a vegetação em uma floresta amazônica tropical, foi criado, em 2001, um projeto de pesquisa de longo prazo, denominado Projeto Seca Floresta (ESECAFLOR). Seu principal objetivo é determinar como uma redução significativa da água disponível no solo, em longo prazo, pode afetar a biota. O ESECAFLOR consiste em duas parcelas de um hectare, a parcela experimental é recoberta com 6 mil painéis plásticos, reduzindo a precipitação em $50 \%$. O objetivo deste trabalho é comparar a florística e a estrutura de plantas $(<2$ metros de altura) entre a parcela experimental e o controle do ESECAFLOR. Houve redução significativa na riqueza e na diversidade de espécies, na densidade e na altura das plantas, e mudança significativa da composição de espécies entre a parcela experimental em comparação com a de controle. A comunidade de plantas respondeu claramente à redução da umidade do solo na parcela experimental, corroborando os resultados de alguns modelos climáticos segundo os quais a redução de chuvas na Amazônia vai afetar negativamente a comunidade de plantas.

Palavras-chave: Efeito da seca. Disponibilidade de água no solo. Comunidade de plantas. Floresta amazônica.

FERREIRA, L. V., D. A. CUNHA, P. PAROLIN \& A. C. L. COSTA, 2017. Impacts of experimental drought on community structure and floristic composition of tree saplings in a lowland tropical rainforest in Eastern Amazonia. Boletim do Museu Paraense Emílio Goeldi. Ciências Naturais 11(3): 351-363.

Autor para correspondência: Leandro Valle Ferreira. Museu Paraense Emílio Goeldi/MCTIC. Coordenação de Botânica. Avenida Perimetral, 1901 - Terra Firme. Belém, PA, Brasil. CEP 66077-530 (lvferreira@museu-goeldi.br).

Recebido em 04/03/2015

Aprovado em 22/05/2017

Responsabilidade editorial: Maria de Lourdes Pinheiro Ruivo e Rogério Rosa da Silva

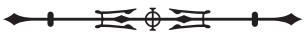




\section{INTRODUCTION}

Increasingly severe and frequent droughts may be considered one of the major threats to Amazon lowland rainforests, at the present and even more so in the future (Laurance et al., 2001, 2002; Phillips et al., 2009). Forests worldwide, and lowland tropical rainforests in particular, will undergo changes in species composition and structure. It remains unclear how quickly tropical vegetation may change (Condit et al., 1995).

In recent years several studies have reported possible global changes associated with potential drought (Asner et al., 2009; Stickler et al., 2009; Stork et al., 2009). Global warming might increase the frequency of $E l$ Niño events (Timmerman et al., 1999), an occurrence that would dramatically increase the vulnerability of Amazonian forests to droughts and fires (Laurance \& Williamson, 2001; Laurance et al., 2002; Cochrane \& Barber, 2009). El Niño-Southern Oscillation (ENSO) droughts may increase in intensity and frequency, and cause drastic reductions of precipitation (Nepstad et al., 2007). Land-atmosphere global climate models predict a widespread dieback of Amazonian forest cover through reduced precipitation (Barlow \& Peres, 2008).

Reductions of water in the forest system cause considerable alterations, such as elevated tree mortality, increased litterfall, shifts in plant phenology, and other ecological changes, especially near forest edges, as well as increased forest loss, fragmentation, and regional climate change (Laurance \& Williamson, 2001; Nepstad et al., 2007). A considerable increase of the susceptibility to forest fires may result from the combined effects of El Niño-induced droughts and land-use change, with all consequences on rates of tree mortality, changes in forest structure, biomass loss and carbon emissions (Barlow \& Peres, 2004; Righi et al., 2009).

The effects of reduced precipitation on vegetation can be drastic (Clark, 2007; Guariguata et al., 2008). Drought strongly decreases growth, biomass, transpiration and photosynthetic activity (Poorter \& Markesteijn, 2008; Parolin et al., 2010), and influences phenological rhythms (Borchert et al., 2002). Physiological responses of trees to drought result in changes of vegetation cover, species composition and shifts of dominant functional groups (Conditet al., 1996; Wright et al., 2004; Cai et al., 2009). Emerging seedlings and saplings may be filtered with a shift towards more drought-tolerant species (Engelbrecht et al., 2002, 2007; Bunker \& Carson, 2005; Poorter \& Markesteijn, 2008) or functional groups. Shifts from trees to lianas may occur, as lianas fix more carbon and use water and nitrogen more efficiently than trees, particularly during seasonal drought, which may confer a competitive advantage to lianas during the dry season (Cai et al., 2009). Thus, changes to drier climates promote increases in both liana abundance and their proportion in the flora (Wright et al., 2004; Nepstad et al., 2007). Also, overall life-history strategies may change, e.g., from opportunistic generalist species vs. shade-tolerant undergrowth specialists, since interactions between lifehistory, disturbance regime and distribution pattern mediate whether particular species will be exposed to increased extinction risks under climate change (Akcakaya et al., 2008).

To test the effects of lower water availability on the vegetation of a lowland tropical rainforest in eastern Amazonian, the ESECAFLOR project was set up with long-term study plots in 2001. ESECAFLOR consists of a simulation of extended extreme drought in an ombrophilous forest. It was established to evaluate the impact of drought on water and carbon cycles. In the present paper, we analyze the effects of simulated drought on forest regeneration. The objective of this study was to compare the floristics (species richness, diversity and species composition) and structure (absolute abundance) of sapling (plants shorter than $2 \mathrm{~m}$ ) communities in a water-exclusion and a control plot. The aim of the project was to determine how soil water availability affects the structure, floristics, and composition of tree sapling species.

\section{MATERIAL AND METHODS}

The Scientific Station Ferreira Penna, also called Caxiuanã, is located in the municipality of Melgaço (10 13' 86" S; 48 17' 41.18 " W), about $411 \mathrm{~km}$ west of Belém, in the basin of the 
Caxiuanã River and bay in eastern Amazonia (Figures 1A-1B). It is covered by dense ombrophilous lowland primary and secondary forests of different ages (Almeida et al., 1993) and two types of floodplain forests, flooded by nutrient-rich white-water rivers (várzea) and by nutrient-poor black-water rivers (igapós) (Ferreira et al., 2005). The experimental plots were carefully chosen based on tree species composition and under identical conditions of topography and soil. The distance between the plots was $500 \mathrm{~m}$ (Da Costa, 2008).

Two plots of 1 ha each $(100 \times 100 \mathrm{~m})$ were established, one of which was left as it was (control C) while the other one was artificially covered by plastic sheets (experimental E) in 2001 in order to impose an artificial drought on the vegetation (Da Costa, 2008).

In the experimental plot, trenches with depths between 50 and $150 \mathrm{~cm}$ were dug, and 6,000 transparent plastic panels that do not impede the passage of light were installed at an average height of 1.5 to $3.5 \mathrm{~m}$ above of the ground (Figure 2). These panels direct the falling rain water into gutters, isolated with waterproof plastic and with an inclination of $2 \mathrm{~m}$ between one side of the study plot and the other, so that off-flowing water was directed into the trenches. This brought about a 50\% exclusion of rain in plot $E$ as compared to the control plot $C$. The control plot $C$ is used as reference for the experiments carried through in plot $\mathrm{E}$ (experimental hectare).

In each of the $C$ and $E$ plot, 20 sub-plots of $2 \times 2 \mathrm{~m}$ were randomly established, inside of which all saplings between 10 and $200 \mathrm{~cm}$ height were inventoried. Species were determined to the finest possible taxonomic level.

The density and height of individuals and species richness and Shannon-Weaver species diversity between the $C$ and $E$ plots were compared using Student's t-test (Zar, 2010).

The difference in the floristic composition between the $C$ and $E$ plots was compared using Principal Coordinates Analysis (PCoA) and tested by Permutational Multivariate Analysis of Variance (PERMANOVA). The results are presented by PseudoF Index that describes

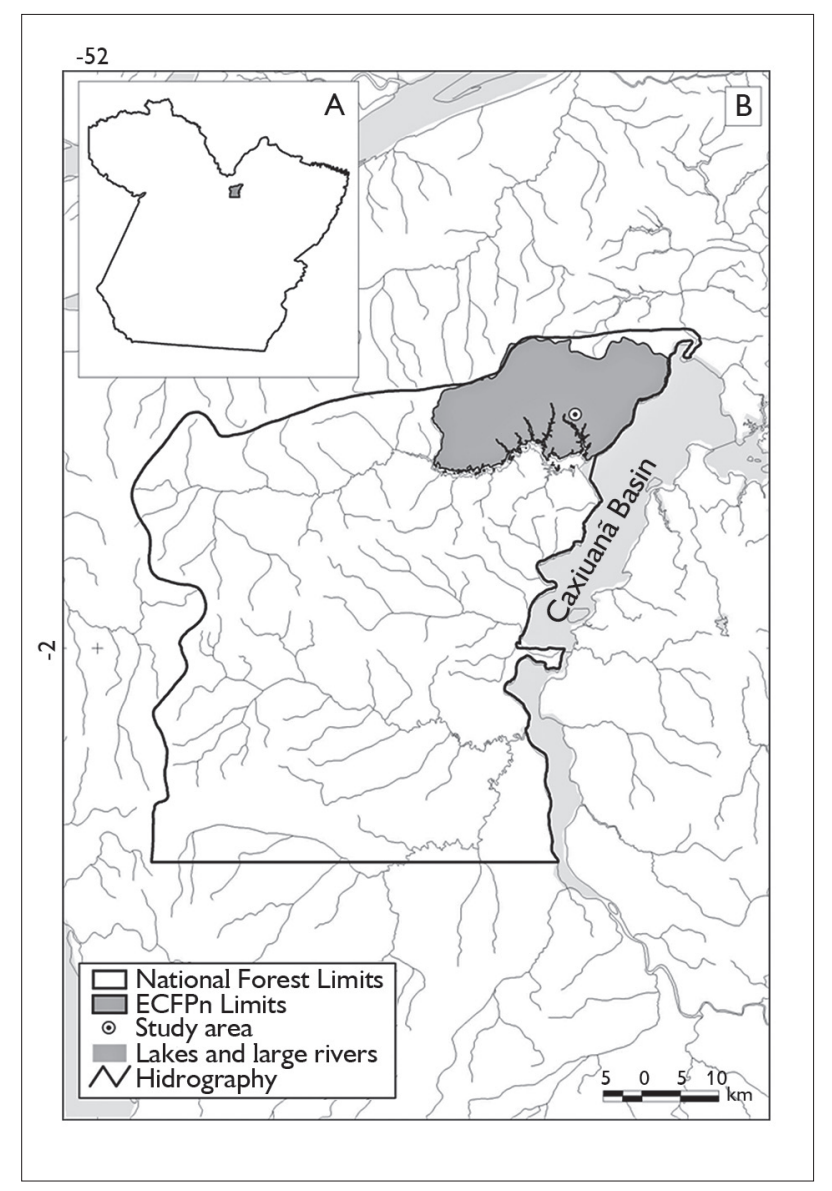

Figure 1. Location of the Ferreira Penna Scientific Station in relation to State of Pará (A) and limits of Ferreira Penna Scientific Station (Estação Científica Ferreira Penna - ECFPn) (B).

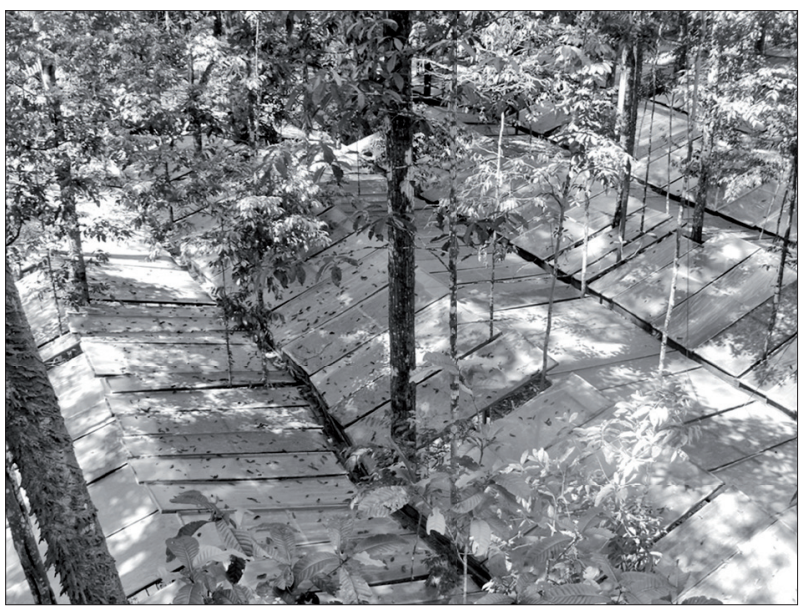

Figure 2. Part of 6,000 transparent plastic panels established in the experimental plot. Photo: L. V. Ferreira.

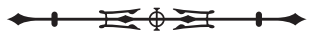


the ratio of between-cluster variance to within cluster variance (Anderson, 2001).

\section{RESULTS}

The total number of species was 129 in the $\mathrm{C}$ plot and 89 in the E plot. Sixty-two tree sapling species were common to both plots, 67 species occurred exclusively in the C plot, and 23 species occurred exclusively in the E plot (Appendix).

The sapling density was significantly higher in the $C$ plot than in the E plot (Mean $(X)=33$; standard deviation $(S D)=12.7)$ and $(X=17.8 ; S D=4.9)(t=5.00 ; P=$ 0.0001), respectively (Figure 3).
The sapling height was significantly greater in the $C$ plot than in the $E$ plot $(X=63.7 ; S D=35.9)$ and $(X=44.8 ; S D=12.5)(t=2.21 ; P=0.037)$, respectively (Figure 3 ). The species richness was significantly higher in the control plots than in the experimental plots $(X=20.9$; SD $=6.7)$ and $(X=$ 13.2; $S D=2.9)(t=4.62 ; P=0.0001)$, respectively (Figure 3).

The species diversity was significantly higher in the control plots than in the experimental plots $(X=2.80$; $\mathrm{SD}=0.37)$ and $(X=2.26$; $S D=0.22)(t=3.51$; $P=0.001$ ), respectively (Figure 3 ).
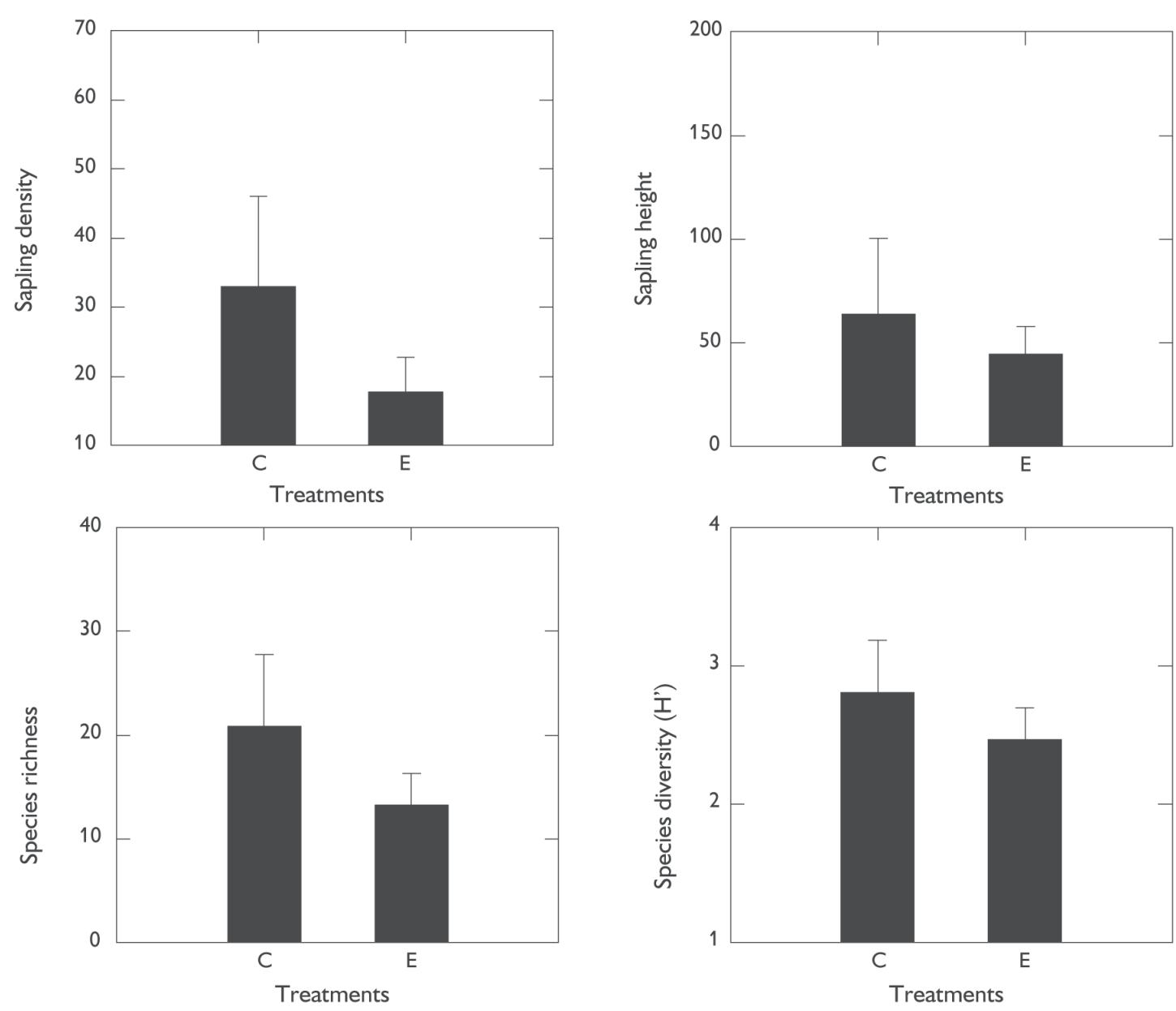

Figure 3. Comparison of sapling density, sapling height, species richness and species diversity between the control (C) and experimental (E) plots.

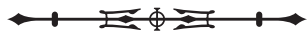


The species composition was significantly different between the control and experimental plots (PseudoF $=$ 2.17; $P=0.005)$ (Figure 4).

\section{DISCUSSION}

This study shows that a significant decrease of soil humidity and probably other variables such as temperature and air humidity (Da Costa, 2008), artificially imposed on an Amazonian lowland tropical forest for seven years caused significant changes in species richness and distribution of life forms of the regenerating vegetation.

This is no surprise, as studies from other tropical forests have documented similar changes, but too little is known about the effects of water shortage in Eastern Amazonia, one of the regions which in future will be severely affected by increasing drought (Nepstad et al., 2007). The extreme drought of 2005 - the worst drought in more than a century - was particularly strong in Amazonia (Marengo et al., 2008), when the Amazon River floodplains dried up. Although it was an atypical drought caused by warmer ocean temperatures, similar events are recurring more and more frequently and with stronger impacts, mostly linked to ENSO events, causing wildfires which destroy thousands of hectares of forest (Alencar et al., 2004).

All changes measured in the drier plots of our study appear to be closely related to the changes of soil humidity. Lower sapling density, height and species richness and species diversity occurred in the plot subjected to water shortage. However, which mechanisms are responsible for these changes in this particular experimental setting cannot be answered with the current state of knowledge. Multiple mechanisms may cause mortality during drought (McDowell et al., 2008). A common mechanism for plants with isohydric regulation of water status results from avoidance of drought-induced hydraulic failure via stomatal closure, resulting in carbon starvation and a cascade of downstream effects such as reduced resistance to biotic agents (Saiki et al., 2017).

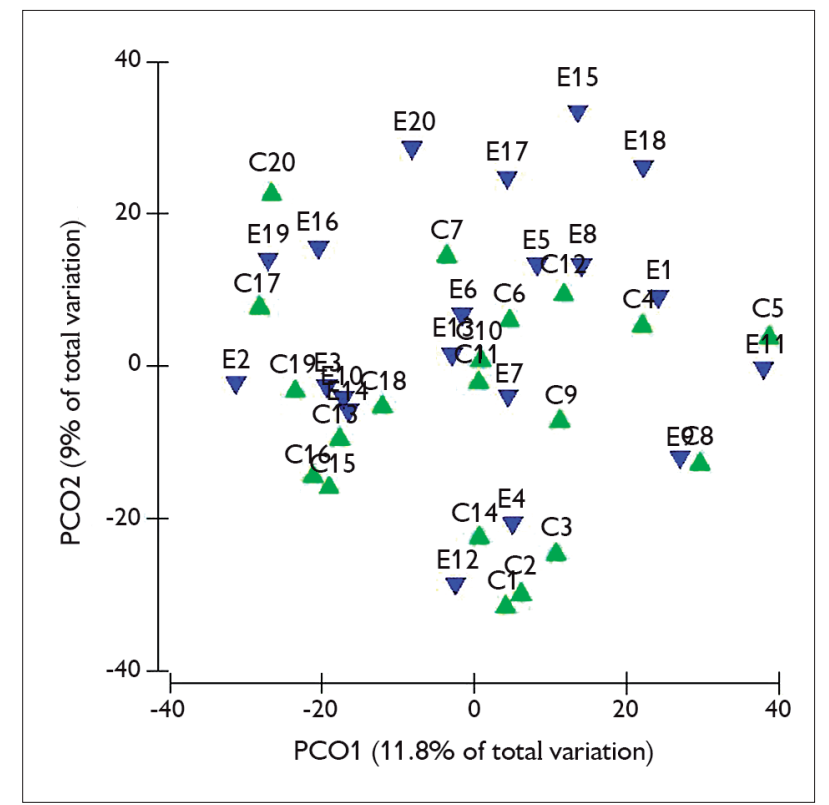

Figure 4. Comparison of species distribution between the control (C) and experimental (E) plots.

These have to be analyzed in detail for the species in the study plots. The most plausible reasons for the measured changes under drought are sapling mortality and regrowth of species with different ecological requirements and perhaps a broader ecological spectrum. In our study water shortage led to reductions of sapling density at community and population levels, emphasizing the close relationship between water availability, habitat associations, patterns of tree species richness and seedling recruitment and survival (Paine et al., 2009). In an experimental approach which did the opposite than our water shortage experiment, supplemental irrigation of a Peruvian rainforest led to enhanced young seedling growth and survival, increasing stem density and diversity (Paine et al., 2009), indicating the fundamental role of water in the establishment phase for the local tree species. To date, the responsibility of physiological mechanisms for survival and mortality under drought are still poorly understood and are only postulated to cause the changes measured in our study.

However, not only diversity is positively correlated with water availability at global, continental and regional scales (Paine et al., 2009). Different functional groups 
also differ in their responses to water stress. Thus, we postulate that the shift towards higher percentages of vines found in our study hectare is an indication for a shift to more generalist species that have better survival chances and are tolerant of varying hydric conditions rather then occupying only small ecological niches as most Amazonian tree species (Nascimento et al., 2005).

In the future, the importance of wider tolerance and response spectra for species survival may increase. If to date the high species diversity in Amazonian forests is related to a high specialization and niche compartmentalization (Walker, 1987), in the future these specialist species may be the losers and give way to generalist opportunistic species that can colonize sites with constantly changing water stress conditions. Amazonian floodplain forests may give us hope, because there hydric stress for trees is a recurrent phenomenon - in both terms of water excess and shortage (Parolin, 2001; Parolin et al., 2010), and yet these forests maintain a very high diversity of species (Wittmann et al., 2006) and functional groups. This indicates that extreme drought events will not necessarily drain all tree life forms from the existing forest. However, overall diversity will be reduced within very short time spans, with all the consequences for the ecosystem equilibrium and carbon balances which exert a strong worldwide influence (SoaresFilho et al., 2006; Phillips et al., 2009).

It is not a question whether hydric changes will occur that affect lowland forests. They always have occurred in form of El Niño-ENSO events, e.g. in the years 1983, 1992, 1997, 1998, and 2003 precipitation was only slightly above $1,500 \mathrm{~mm}$ as compared to 2,000 $\mathrm{mm}$ in normal years. And, as we know, they are strongly increasing in frequency and severity (Da Costa et al., 2009). However, for the scientific community the question is how the forests will respond to increasing hydric stress events. As the results of our study indicate, we must expect strong shifts of species and functional groups after only a few years. Few species present the necessary adaptations to tolerate a wide range of hydric conditions, and only these have a chance of survival.
Changes in land use, such as urbanization, cultivation, and pastures, have been generally considered to be one of the main factors impacting Amazonian biodiversity. However, the impacts related to climatic changes are far more worrying, especially because its effects on biodiversity are still little studied. The Amazon region can be categorized as a region of great risk because of its social and climatic variability, and the synergic interactions of disordered processes of occupation of the region, leading to deforestation and land use changes. Models indicate the possibility of abrupt and irreversible substitutions of forested areas with open vegetation formations with less biomass, large-scale losses of biodiversity and reductions of the supporting capacity of the region (Nobre et al., 2007).

The loss of species richness and diversity in an Amazonian tropical forests, shown in the present study as a result of artificially simulating drought El Niño events, gives us clear signals that it is necessary to propose strategies for minimizing the climatic impact of changes at global scale

\section{ACKNOWLEDGEMENTS}

The authors thank Plinio Camargo and Scott Saleska for the invitation to participate in the course International Research and Education Project (PIRE). Thanks are also given to the technical coordinator of the Scientific Station Ferreira Penna, Mrs. Rosa Paes, for her help during our stay at the field station, and to Luiz Carlos Batista Lobato, for help during data collection and with species identification.

\section{REFERENCES}

AKCAKAYA, H., D. KEITH, W. THUILLER, G. MIDGLEY, R. PEARSON, S. PHILLIPS, H. M. REGAN, M. B. ARAÚJO \& T. REBELO, 2008. Predicting extinction risks under climate change: integrating stochastic metapopulation models with dynamic bioclimatic habitat models. Annual Meeting of the International Congress for Conservation Biology. Available at: <http://www. allacademic.com/meta/p240064 index.html>. Accessed on: 9 Junho 2017.

ALENCAR, A. A. C., L. A. SOLORZANO \& D. C. NEPSTAD, 2004. Modeling forest understory fires in an eastern Amazonian landscape. Ecological Applications 14(sp4): 139-149. DOI: http:// dx.doi.org/10.1890/01-6029.

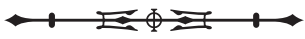


ALMEIDA, S. S., P. L. B. LISBOA \& A. S. L. SILVA, 1993. Diversidade florística de uma comunidade arbórea na Estação Científica "Ferreira Penna", em Caxiuanã (Pará). Boletim do Museu Paraense Emílio Goeldi. Série Botânica 9: 99-128.

ANDERSON, M. J., 2001. A new method for non-parametric multivariate analysis of variance. Austral Ecology 26(1): 32-46.

ASNER, G. P., T. K. RUDEL \& T. M. AIDE, 2009. A contemporary assessment of change in humid tropical forests. Conservation Biology 23(6): 1386-1395. DOI: http://dx.doi.org/10.1111/j.15231739.2009.01333.x.

BARLOW, J. \& C. A. PERES, 2004. Ecological responses to El Niñoinduced surface fires in central Brazilian Amazonia: management implications for flammable tropical forests. Philosophical Transactions of the Royal Society B 359(1443): 367-380. DOI: http://dx.doi. org/10.1098/rstb.2003.1423.

BARLOW, J. \& C. A. PERES, 2008. Fire-mediated dieback and compositional cascade in an Amazonian forest. Philosophical Transactions ot the Royal Society B 363(1498): 1787-1794. DOI: http://dx.doi.org/10.1098/rstb.2007.0013.

BORCHERT, R., G. RIVERA \&W. HAGNAUER, 2002. Modification of vegetative phenology in a tropical semi-deciduous forest by abnormal drought and rain. Biotropica 34(1): 27-39. DOI: http:// dx.doi.org/10.1111/j.1744-7429.2002.tb00239.x.

BUNKER, D. E. \& W. P. CARSON, 2005. Drought stress and tropical forest woody seedlings: effect on community structure and composition. Journal of Ecology 93(4): 794-806. DOI: http://dx.doi. org/10.1111/.j.1365-2745.2005.01019.x.

CAI, Z.-Q., S. A. SCHNITZER \& F. BONGERS, 2009. Seasonal differences in leaf-level physiology give lianas a competitive advantage over trees in a tropical seasonal forest. Oecologia 161(1): 25-33. DOI: http://dx.doi.org/10.1007/s00442-009-1355-4.

CLARK, D. A., 2007. Detecting tropical forests' responses to global climatic and atmospheric change: current challenges and a way forward. Biotropica 39(1): 4-19. DOI: http://dx.doi.org/10.1111/ j.1744-7429.2006.00227.x.

COCHRANE, M. A. \& C. P. BARBER, 2009. Climate change, human land use and future fires in the Amazon. Global Change Biology 15(3): 601-612. DOI: http://dx.doi.org/10.1111/j.13652486.2008.01786.x.

CONDIT, R., S. P. HUBBELL \& R. B. FOSTER, 1995. Mortality rates of 205 Neotropical tree and shrub species and the impact of a severe drought. Ecological Monographs 65(4): 419-439. DOI: http://dx.doi.org/10.2307/2963497.

CONDIT, R., S. P. HUBBELL \& R. B. FOSTER, 1996. Assessing the response of plant functional types to climatic change in tropical forests. Journal of Vegetation Science 7(3): 405-416. DOI: http:// dx.doi.org/10.2307/3236284.
DA COSTA, A. C. L., 2008. Projeto ESECAFLOR (Estudo da Seca da Floresta): Relatório Final: 1-68. Conselho Nacional de Desenvolvimento Científico e Tecnológico (CNPq), Belém.

DA COSTA, A. C. L., S. S. ALMEIDA, C. R. CARVALHO, P. MEIR, Y. MALHI, R. F. COSTA, J. A. S. JÚNIOR, M. C. COSTA, B. T. TANAKA, R. A. FISHER, E. D. SOTTA, L. L. OLIVEIRA, P. H. L. GONÇALVES, A. P. BRAGA \& P. N. BARRETO, 2009. Experimento ESECAFLORLBA em Caxiuanã. In: P. L. B. LISBOA (Ed.): Caxiuanã: desafios para a conservação de uma Floresta Nacional na Amazônia: 45-97. Museu Paraense Emílio Goeldi, Belém.

ENGELBRECHT, B. M. J., S. J. WRIGHT \& D. DE STEVEN, 2002. Survival and ecophysiology of tree seedlings during El Ninõ drought in a tropical moist forest in Panama. Journal of Tropical Ecology 18(4): 569-579. DOI: https://doi.org/10.1017/S0266467402002377.

ENGELBRECHT, B. M. J., L. S. COMITA, R. CONDIT, T. A. KURSAR, M. T. TYREE, B. L. TURNER \& S. P. HUBBELL, 2007. Drought sensitivity shapes species distribution patterns in tropical forests. Nature 447: 80-82. DOI: http://dx.doi.org/10.1038/nature05747.

FERREIRA, L. V., S. S. ALMEIDA, D. D. AMARAL \& P. PAROLIN, 2005. Riqueza e composição de espécies da floresta de igapó e várzea da Estação Científica Ferreira Penna: subsídios para o plano de manejo da Floresta Nacional de Caxiuanã. Pesquisas, Botânica 56: 103-116.

GUARIGUATA, M. R., J. P. CORNELIUS, B. LOCATELLI, C. FORNER \& G. A. SÁNCHEZ-AZOFEIFA, 2008. Mitigation needs adaptation: tropical forestry and climate change. Mitigation and Adaptation Strategies for Global Change 13(8): 793-808

LAURANCE, W. F. \& G. B. WILLIAMSON, 2001. Positive feedbacks among forest fragmentation, drought, and climate change in the Amazon. Conservation Biology 15(6): 1529-1535. DOI: http://dx.doi. org/10.1046/j.1523-1739.2001.01093.x.

LAURANCE, W. F., M. A. COCHRANE, S. BERGEN, P. M. FEARNSIDE, P. DELAMÔNICA, C. BARBER, S. D'ANGELO \& T. FERNANDES, 2001. Environment: the future of the Brazilian Amazon. Science 291(5503): 438-439. DOI: http://dx.doi.org/10.1126/ science.291.5503.438.

LAURANCE, W. F., G. POWELL \& L. HANSEN, 2002. A precarious future for Amazonia. Trends in Ecology \& Evolution 17(6): 251-252. DOI: http://dx.doi.org/10.1016/S0169-5347(02)02484-9.

MARENGO, J. A., C. A. NOBRE, J. TOMASELLA, M. D. OYAMA, G. SAMPAIO DE OLIVEIRA, R. OLIVEIRA, H. CAMARGO, L. M. ALVES \& I. F. BROWN, 2008. The drought of Amazonia in 2005. Journal of Climate 21(3): 495-516. DOI: https://doi.org/10.1175/2007JCLI1600.1.

MCDOWELL, N., W. T. POCKMAN, C. D. ALLEN, D. D. BRESHEARS, N. COBB, T. KOLB, J. PLAUT, J. SPERRY, A. WEST, D. G. WILLIAMS \& E. A. YEPEZ, 2008. Mechanisms of plant survival and mortality during drought: why do some plants survive while others succumb to drought? New Phytologist 178(4): 719739. DOI: https://doi.org/10.1111/j.1469-8137.2008.02436.x.

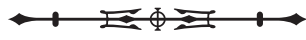


NASCIMENTO, H. E. M., W. F. LAURANCE, R. CONDIT, S. G. LAURANCE, S. D'ANGELO \& A. C. ANDRADE, 2005. Demographic and life-history correlates for Amazonian trees. Journal of Vegetation Science 16(6): 625-634. DOI: http://dx.doi. org/10.1111/j.1654-1103.2005.tb02405.x.

NEPSTAD, D. C., I. M. TOHVER, D. RAY, P. MOUTINHO \& G. CARDINOT, 2007. Mortality of large trees and lianas following experimental drought in an Amazon forest. Ecology 88(9): 22592269. DOI: http://dx.doi.org/10.1890/06-1046.1.

NOBRE, A. C., G. SAMPAIO \& L. SALAZAR, 2007. Mudanças climáticas e Amazônia. Ciência e Cultura 59(3): 22-27.

PAINE, C. E. T., K. E. HARMS \& J. RAMOS, 2009. Supplemental irrigation increases seedling performance and diversity in a tropical forest. Journal of Tropical Ecology 25(2): 171-180. DOI: https:// doi.org/10.1017/S0266467408005798.

PAROLIN, P., 2001. Morphological and physiological adjustments to waterlogging and drought in seedlings of Amazonian floodplain trees. Oecologia 128(3): 326-335. DOI: https://doi.org/10.1007/ s004420100660.

PAROLIN, P., C. LUCAS, M. T. F. PIEDADE \& F. WITTMANN, 2010. Drought responses of extremely flood-tolerant trees of Amazonian floodplains. Annals of Botany 105(1): 129-139. DOI: http://dx.doi.org/10.1093/aob/mcp258.

PHILLIPS, O. L., L. E. O. C. ARAGÃO, S. L. LEWIS, J. B. FISHER, J. L. LLOYD, G. LOPEZ-GONZALEZ, Y. MALHI, A. MONTEAGUDO, J. PEACOCK, C. A. QUESADA, G. VAN DER HEIJDEN, S. S. ALMEIDA, I. AMARAL, L. ARROYO, S. AYMARD, T. R. BAKER, O. BANKI, L. BLANC, D. BONAL, P. BRANDO, J. CHAVE, A. C. A. OLIVEIRA, N. D. CARDOZO, C. I. CZIMCZIK, T. R. FELDPAUSCH, M. A. FREITAS, E. GLOOR, N. HIGUCHI, E. JIMENEZ, G. LLOYD, P. MEIR, C. MENDOZA, A. MOREL, D. A. NEILL, D. NEPSTAD, S. PATINO, M. C. PENUELA, A. PRIETO, F. RAMIREZ, M. SCHWARZ, J. SILVA, M. SILVEIRA, A. S. THOMAS, H. TER STEEGE, J. STROPP, R. VASQUEZ, P. ZELAZOWSKI, E. A. DAVILA, S. ANDELMAN, A. ANDRADE, K. J. CHAO, T. ERWIN, A. DI FIORE, K. EHCH, T. J. KILLEEN, W. F. LAURANCE, A. P. CRUZ, N. C. A. PITMAN, P. N. VARGAS, H. RAMIREZ-ANGULO, A. RUDAS, R. SALOMÃO, N. SILVA, J. TERBORGH \& A. TORRES-LEZAMA, 2009. Drought sensitivity of the Amazon rainforest. Science 323(5919): 1344-1347. DOI: http://dx.doi.org/10.1126/science.1164033.

POORTER, L. \& L. MARKESTEIJN, 2008. Seedling traits determine drought tolerance of tropical tree species. Biotropica 40(3): 321331. DOI: https://doi.org/10.1111/j.1744-7429.2007.00380.x.
RIGHI, C. A., P. M. L. D. GRAÇA \& C. C. CERRI, 2009. Biomass burning in Brazil's Amazonian "arc of deforestation": burning efficiency and charcoal formation in a fire after mechanized clearing at Feliz Natal, Mato Grosso. Forest Ecology and Management 258(11): 2535-2546. DOI: https://doi.org/10.1016/j.foreco.2009.09.010.

SAIKI, S.-T., A. ISHIDA, K. YOSHIMURA \& K. YAZAKI, 2017. Physiological mechanisms of drought-induced tree die-off in relation to carbon, hydraulic and respiratory stress in a drought-tolerant woody plant. Scientific Reports (2995): 1-10. DOI: http://dx.doi.org/10.1038/ s41598-017-03162-5.

SOARES-FILHO, B. S., D. C. NEPSTAD, L. M. CURRAN, G. C. CERQUeIRA, R. A. GARCIA, C. A. RAMOS, E. VOLL, A. MCDONALD, P. LEFEBVRE \& P. SCHLESINGER, 2006. Modelling conservation in the Amazon basin. Nature 440: 520-523. DOI: http:// dx.doi.org/10.1038/nature04389.

STICKLER, C. M., D. C. NEPSTAD \& M. T. COE, 2009. The potential ecological costs and cobenefits of REDD: a critical review and case study from the Amazon region. Global Change Biology 15(12): 28032824. DOI: http://dx.doi.org/10.1111/f.1365-2486.2009.02109.x.

STORK, N. E., J. A. CODDINGTON \& R. K. COLWELL, 2009. Vulnerability and resilience of tropical forest species to land-use change. Conservation Biology 23(6): 1438-1447. DOI: http://dx.doi. org/10.1111/j.1523-1739.2009.01335.x.

TIMMERMAN, A., J. OBERHUBER, A. BACHER, M. ESCH, M. LATIF \& E. ROECKNER, 1999. Increased El Niño frequency in a climate model forced by future greenhouse warming. Nature 398: 694-697. DOI: http://dx.doi.org/10.1038/19505.

WALKER, I., 1987. Compartmentalization and niche differentiation: causal patterns of competition and coexistence. Acta Biotheoretica 36(4): 215-239. DOI: http://dx.doi.org/10.1007/BF02329784.

WITTMANN, F., J. SCHÖNGART, J. C. MONTERO, T. MOTZER, W. J. JUNK, M. T. F. PIEDADE, H. L. QUEIROZ \& M. WORBES, 2006. Tree species composition and diversity gradients in white-water forests across the Amazon Basin. Journal of Biogeography 33(8): 1334-1347. DOI: http://dx.doi.org/10.1111/.1365-2699.2006.01495.x.

WRIGHT, S. J., O. CALDERÓN, A. HERNANDÉZ \& S. PATON, 2004. Are lianas increasing in importance in tropical forests? A 17-year record from Panama. Ecology 85(2): 484-489. DOI: http://dx.doi. org/10.1890/02-0757.

ZAR, J. H., 2010. Biostatistical analysis: 5. ed.: 1-960. Prentice-Hall, Englewood Cliffs, New Jersey.

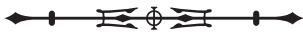


APPENDIX. List of species in decreasing density in the control (C) and experimental (E) plots of the ESECAFLOR Project. (Continue)

\begin{tabular}{|c|c|c|c|c|c|c|}
\hline$\#$ & Species & Family & Life form & Plot C & Plot E & Total \\
\hline 1 & Pouteria cladantha Sandwith & Sapotaceae & Arboreal & 43 & 19 & 62 \\
\hline 2 & Vouacapoua americana Aubl. & Caesalpinaceae & Arboreal & 44 & 15 & 59 \\
\hline 3 & Lecythis idatimon Aubl. & Lecythidaceae & Arboreal & 34 & 21 & 55 \\
\hline 4 & Faramea bracteata Benth. & Rubiaceae & Shrubby & 40 & 11 & 51 \\
\hline 5 & Rinorea guianensis Aubl. & Violaceae & Arboreal & 31 & 8 & 39 \\
\hline 6 & Doliocarpus dentatus (Aubl.) Standl. & Dilleniaceae & Liana & 20 & 12 & 32 \\
\hline 7 & Memora flavida (DC.) Bureau \& K. Schum. & Bignoniaceae & Liana & 11 & 19 & 30 \\
\hline 8 & Inga alba (Sw.) Willd. & Mimosaceae & Arboreal & 17 & 11 & 28 \\
\hline 9 & Protium apiculatum Swart & Burseraceae & Arboreal & 18 & 8 & 26 \\
\hline 10 & Qualea paraensis Ducke & Vochysiaceae & Arboreal & 17 & 7 & 24 \\
\hline 11 & Eugenia coffeifolia DC. & Myrtaceae & Shrubby & 8 & 14 & 22 \\
\hline 12 & Duguetia echinophora R.E. Fr. & Annonaceae & Arboreal & 20 & 1 & 21 \\
\hline 13 & Inga lateriflora Miq. & Mimosaceae & Arboreal & 9 & 12 & 21 \\
\hline 14 & Protium pilosissimum Engl. & Burseraceae & Arboreal & 10 & 11 & 21 \\
\hline 15 & Licania membranacea Sagot ex Laness. & Chrysobalanaceae & Arboreal & 13 & 7 & 20 \\
\hline 16 & Cheiloclinium cognatum (Miers) A.C. Sm. & Hippocrateaceae & Liana & 8 & 10 & 18 \\
\hline 17 & Licania canescens Benoist & Chrysobalanaceae & Arboreal & 13 & 5 & 18 \\
\hline 18 & Monotagma floribundum Hagberg \& R. Erikss. & Marantaceae & Herbaceous & 5 & 10 & 15 \\
\hline 19 & Rinorea passoura Kuntze & Violaceae & Arboreal & 7 & 8 & 15 \\
\hline 20 & Salacia impressifolia (Miers) A.C. Sm. & Hippocrateaceae & Liana & 7 & 8 & 15 \\
\hline 21 & Psychotria racemosa Rich. & Rubiaceae & Shrubby & 4 & 10 & 14 \\
\hline 22 & Mouriri callocarpa Ducke & Melastomataceae & Arboreal & 10 & 3 & 13 \\
\hline 23 & Swartzia recurva Poepp. & Fabaceae & Arboreal & 6 & 6 & 12 \\
\hline 24 & Memora schomburgkii (DC.) Miers & Bignoniaceae & Liana & 9 & 2 & 11 \\
\hline 25 & Brosimum rubescens Taub. & Moraceae & Arboreal & 9 & 1 & 10 \\
\hline 26 & Bauhinia guianensis Aubl. & Caesalpinaceae & Liana & 4 & 5 & 9 \\
\hline 27 & Duguetia cadaverica Huber & Annonaceae & Arboreal & 7 & 2 & 9 \\
\hline 28 & Moutabea guianensis Aubl. & Polygalaceae & Liana & 5 & 4 & 9 \\
\hline 29 & Ouratea discophora Ducke & Ochnaceae & Arboreal & 4 & 5 & 9 \\
\hline 30 & Astrocaryum aculeatum G. Mey. & Arecacae & Arboreal & 3 & 5 & 8 \\
\hline 31 & Dinizia excels Ducke & Mimosaceae & Arboreal & 3 & 5 & 8 \\
\hline 32 & Iryanthera laevis Markgr. & Myristicaceae & Arboreal & 8 & & 8 \\
\hline 33 & Minquartia guianensis Aubl. & Olacaceae & Arboreal & 6 & 2 & 8 \\
\hline 34 & Monotagma acuminata & Marantaceae & Herbaceous & 6 & 2 & 8 \\
\hline 35 & Protium tenuifolium (Engl.) Engl. & Burseraceae & Arboreal & 7 & 1 & 8 \\
\hline 36 & Abuta sandwithiana Krukoff \& Barneby & Menispermaceae & Liana & 5 & 2 & 7 \\
\hline 37 & Aniba parviflora (Meisn.) Mez & Lauraceae & Arboreal & 4 & 3 & 7 \\
\hline
\end{tabular}


APPENDIX.

\begin{tabular}{|c|c|c|c|c|c|c|}
\hline \multicolumn{6}{|c|}{ APPENDIX. } & \multirow{2}{*}{ Continue } \\
\hline \# & Species & Family & Life form & Plot C & Plot E & \\
\hline 38 & Connarus erianthus Benth. ex Baker & Connaraceae & Liana & 7 & & 7 \\
\hline 39 & Cordia nodosa Lam. & Boraginaceae & Arboreal & 4 & 2 & 6 \\
\hline 40 & Eschweilera coriacea (DC.) S.A. Mori & Lecythidaceae & Arboreal & 6 & & 6 \\
\hline 41 & Paypayrola grandifolia Tul. & Violaceae & Arboreal & 2 & 4 & 6 \\
\hline 42 & Pouteria anibiifolia (A.C. Smith.) Aubr. & Sapotaceae & Arboreal & 6 & & 6 \\
\hline 43 & Pouteria filipes Eyma & Sapotaceae & Arboreal & 4 & 2 & 6 \\
\hline 44 & Protium subserratum (Engl.) Engl. & Burseraceae & Arboreal & 3 & 3 & 6 \\
\hline 45 & Sloanea eichleri K. Schum. & Elaeocarpaceae & Arboreal & 4 & 2 & 6 \\
\hline 46 & Virola michelii Heckel & Myristicaceae & Arboreal & 4 & 2 & 6 \\
\hline 47 & Aspidosperma nitidum Benth. ex Müll. Arg. & Apocynaceae & Arboreal & 5 & & 5 \\
\hline 48 & Ischnosiphon arouma (Aubl.) Körn. & Marantaceae & Herbaceous & 5 & & 5 \\
\hline 49 & Micropholis venulosa (Mart. \& Eichler) Pierre & Sapotaceae & Arboreal & 5 & & 5 \\
\hline 50 & Ocotea canaliculata (Rich.) Mez & Lauraceae & Arboreal & 4 & 1 & 5 \\
\hline 51 & Pouteria decorticans T.D. Penn. & Sapotaceae & Arboreal & 4 & 1 & 5 \\
\hline 52 & Prionostemma asperum (Lam.) Miers & Hippocrateaceae & Liana & & 5 & 5 \\
\hline 53 & Protium decandrum (Aubl.) Marchand & Burseraceae & Arboreal & 4 & 1 & 5 \\
\hline 54 & Psychotria colorata (Willd. ex Roem. \& Schult.) Müll. Arg. & Rubiaceae & Shrubby & 2 & 3 & 5 \\
\hline 55 & Astronium gracile Engl. & Anacardiaceae & Arboreal & 3 & 1 & 4 \\
\hline 56 & Derris floribunda (Benth.) Ducke & Fabaceae & Liana & 4 & & 4 \\
\hline 57 & Eugenia cupulata Amshoff & Myrtaceae & Arboreal & & 4 & 4 \\
\hline 58 & Hymenolobium petraeum Ducke & Leg_Papilionoidae & Arboreal & 4 & & 4 \\
\hline 59 & Inga gracilis Jungh. ex Miq. & Mimosaceae & Arboreal & 2 & 2 & 4 \\
\hline 60 & Ocotea caudate (Nees) Mez & Lauraceae & Arboreal & 1 & 3 & 4 \\
\hline 61 & Protium spruceanum (Benth.) Engl. & Burseraceae & Arboreal & 4 & & 4 \\
\hline 62 & Strychnos amazonica Krukoff & Loganiaceae & Liana & 4 & & 4 \\
\hline 63 & Stryphnodendron paniculatum Poepp. & Mimosaceae & Arboreal & 4 & & 4 \\
\hline 64 & Astrocaryum gynacanthum Mart. & Arecacae & Arboreal & 2 & 1 & 3 \\
\hline 65 & Erythroxylum micranthum Bong. ex Peyr. & Erythroxylaceae & Shrubby & 2 & 1 & 3 \\
\hline 66 & Geonoma bacculifera (Poit.) Kunth & Arecacae & Shrubby & 1 & 2 & 3 \\
\hline 67 & Manilkara huberi (Ducke) A. Chev. & Sapotaceae & Arboreal & 2 & 1 & 3 \\
\hline 68 & Miconia splendens (Sw.) Griseb. & Melastomataceae & Arboreal & 2 & 1 & 3 \\
\hline 69 & Parinari excels Sabine & Chrysobalanaceae & Arboreal & 2 & 1 & 3 \\
\hline 70 & Pouteria guianensis Aubl. & Sapotaceae & Arboreal & 3 & & 3 \\
\hline 71 & Psychotria poeppigiana Müll. Arg. & Rubiaceae & Shrubby & 2 & 1 & 3 \\
\hline 72 & Swartzia arborescens (Aubl.) Pittier & Fabaceae & Arboreal & 3 & & 3 \\
\hline 73 & Trichilia micrantha Benth. & Meliaceae & Arboreal & & 3 & 3 \\
\hline 74 & Anacampta flavencens & Apocynaceae & Shrubby & 2 & & 2 \\
\hline
\end{tabular}


APPENDIX.

\begin{tabular}{|c|c|c|c|c|c|c|}
\hline \multicolumn{2}{|c|}{ APPENDIX. } & \multicolumn{4}{|c|}{$x_{1}$} & Continue) \\
\hline \# & Species & Family & Life form & Plot C & Plot E & Total \\
\hline 75 & Arrabidaea cinnamomea (DC.) Sandwith & Bignoniaceae & Liana & 2 & & 2 \\
\hline 76 & Banisteriopsis lucida (Rich.) Small & Malpighiaceae & Liana & & 2 & 2 \\
\hline 77 & Couratari guianensis Aubl. & Lecythidaceae & Arboreal & 2 & & 2 \\
\hline 78 & Endlicheria bracteata Mez & Lauraceae & Arboreal & 1 & 1 & 2 \\
\hline 79 & Guarea kunthiana A. Juss. & Meliaceae & Arboreal & 2 & & 2 \\
\hline 80 & Helicostylis pedunculata Benoist & Moraceae & Arboreal & & 2 & 2 \\
\hline 81 & Heliconia psittacorum L. f. & Heliconiaceae & Herbaceous & 1 & 1 & 2 \\
\hline 82 & Hirtella racemosa Lam. & Chrysobalanaceae & Shrubby & 1 & 1 & 2 \\
\hline 83 & Inga macrophylla Humb. \& Bonpl. ex Willd. & Mimosaceae & Arboreal & & 2 & 2 \\
\hline 84 & Inga stipularis DC. & Mimosaceae & Arboreal & 2 & & 2 \\
\hline 85 & Iryanthera paraensis Huber & Myristicaceae & Arboreal & 2 & & 2 \\
\hline 86 & Lacunaria crenata (Tul.) A.C. Sm. & Quiinaceae & Arboreal & 2 & & 2 \\
\hline 87 & Licania apetala (E. Mey.) Fritsch & Chrysobalanaceae & Arboreal & 2 & & 2 \\
\hline 88 & Maquira sclerophylla (Ducke) C.C. Berg & Moraceae & Arboreal & 2 & & 2 \\
\hline 89 & Memora allamandiflora Bureau ex K. Schum. & Bignoniaceae & Liana & & 2 & 2 \\
\hline 90 & Moronobea coccinea Aubl. & Clusiaceae & Arboreal & 2 & & 2 \\
\hline 91 & Pouteria eugeniifolia (Pierre) Baehni & Sapotaceae & Arboreal & 1 & 1 & 2 \\
\hline 92 & Protium paniculatum Engl. & Burseraceae & Arboreal & & 2 & 2 \\
\hline 93 & Protium sagotianum Marchand & Burseraceae & Arboreal & 2 & & 2 \\
\hline 94 & Quiina florida Tul. & Quiinaceae & Arboreal & 1 & 1 & 2 \\
\hline 95 & Scyatodenia sp. & Menispermaceae & Liana & & 2 & 2 \\
\hline 96 & Tetracera wildenowiana & Dilleniaceae & Liana & 2 & & 2 \\
\hline 97 & Unonopsis guatterioides (A. DC.) R.E. Fr. & Annonaceae & Arboreal & 1 & 1 & 2 \\
\hline 98 & Vantanea parviflora Lam. & Humiriaceae & Arboreal & & 2 & 2 \\
\hline 99 & Virola calophylla (Spruce) Warb. & Myristicaceae & Arboreal & 1 & 1 & 2 \\
\hline 100 & Acacia multipinnata Ducke & Mimosaceae & Liana & & 1 & 1 \\
\hline 101 & Alchornea schomburgkii Klotzsch & Euphorbiaceae & Arboreal & & 1 & 1 \\
\hline 102 & Alchorneopsis floribunda (Benth.) Müll. Arg. & Euphorbiaceae & Arboreal & 1 & & 1 \\
\hline 103 & Allophylus divaricatus Radlk. & Sapindaceae & Arboreal & 1 & & 1 \\
\hline 104 & Anaxagorea amazonica & Annonaceae & Arboreal & 1 & & 1 \\
\hline 105 & Arrabidaea bilabiata (Sprague) Sandwith & Bignoniaceae & Liana & 1 & & 1 \\
\hline 106 & Aspidosperma auriculatum Markgr. & Apocynaceae & Arboreal & & 1 & 1 \\
\hline 107 & Brosimum guianense (Aubl.) Huber & Moraceae & Arboreal & 1 & & 1 \\
\hline 108 & Caryocar glabrum (Aubl.) Pers. & Caryocaraceae & Arboreal & 1 & & 1 \\
\hline 109 & Casearia decandra Jacq. & Flacourtiaceae & Arboreal & & 1 & 1 \\
\hline 110 & Cissampelus sp. & Menispermaceae & Liana & 1 & & 1 \\
\hline 111 & Couma guianensis Aubl. & Apocynaceae & Arboreal & & 1 & 1 \\
\hline
\end{tabular}


APPENDIX.

\begin{tabular}{|c|c|c|c|c|c|c|}
\hline \multicolumn{6}{|c|}{ APPENDIX. } & \multirow{2}{*}{ Continue } \\
\hline \# & Species & Family & Life form & Plot C & Plot E & \\
\hline 112 & Dioclea bicolor Benth. & Fabaceae & Liana & 1 & & 1 \\
\hline 113 & Diospyros praetermissa Sandwith & Ebenaceae & Arboreal & 1 & & 1 \\
\hline 114 & Ecclinusa ramiflora Mart. & Sapotaceae & Arboreal & & 1 & 1 \\
\hline 115 & Eugenia flavescens DC. & Myrtaceae & Shrubby & 1 & & 1 \\
\hline 116 & Guatteria olivacea R.E. Fr. & Annonaceae & Arboreal & 1 & & 1 \\
\hline 117 & Hippocratea ovate Lam. & Hippocrateaceae & Liana & 1 & & 1 \\
\hline 118 & Inga brachyrhachys & Mimosaceae & Shrubby & 1 & & 1 \\
\hline 119 & Inga grandifolia Pittier & Mimosaceae & Arboreal & 1 & & 1 \\
\hline 120 & Inga marginata Willd. & Mimosaceae & Arboreal & 1 & & 1 \\
\hline 121 & Inga nobilis Willd. & Mimosaceae & Arboreal & 1 & & 1 \\
\hline 122 & Inga rubiginosa (Rich.) DC. & Mimosaceae & Arboreal & 1 & & 1 \\
\hline 123 & Lacunaria jenmanii (Oliv.) Ducke & Quiinaceae & Arboreal & & 1 & 1 \\
\hline 124 & Licania gracilis Kleinhoonte & Chrysobalanaceae & Arboreal & & 1 & 1 \\
\hline 125 & Maquina caloneura & Moraceae & Arboreal & & 1 & 1 \\
\hline 126 & Matayba arborescens (Aubl.) Radlk. & Sapindaceae & Arboreal & 1 & & 1 \\
\hline 127 & Miconia ciliate (Rich.) DC. & Melastomataceae & Shrubby & 1 & & 1 \\
\hline 128 & Miconia holosericea (L.) DC. & Melastomataceae & Shrubby & 1 & & 1 \\
\hline 129 & Myrcia fallax (Rich.) DC. & Myrtaceae & Arboreal & 1 & & 1 \\
\hline 130 & Myrcia sylvatica (G. Mey.) DC. & Myrtaceae & Arboreal & & 1 & 1 \\
\hline 131 & Ocotea cujumary Mart. & Lauraceae & Arboreal & & 1 & 1 \\
\hline 132 & Palicourea sp. & Rubiaceae & Shrubby & 1 & & 1 \\
\hline 133 & Potalia amara Aubl. & Loganiaceae & Shrubby & 1 & & 1 \\
\hline 134 & Pouteria campanulata Baehni & Sapotaceae & Arboreal & 1 & & 1 \\
\hline 135 & Pouteria gongrijpii Eyma & Sapotaceae & Arboreal & 1 & & 1 \\
\hline 136 & Pouteria robusta (Mart. \& Eichler) Eyma & Sapotaceae & Arboreal & 1 & & 1 \\
\hline 137 & Protium guianense (Aubl.) Marchand & Burseraceae & Arboreal & 1 & & 1 \\
\hline 138 & Guarea kunthiana A. Juss. & Meliaceae & Arboreal & 1 & & 1 \\
\hline 139 & Saccoglotis guianensis Benth. & Humiriaceae & Arboreal & 1 & & 1 \\
\hline 140 & Sagotia brachysepala (Müll. Arg.) Secco & Euphorbiaceae & Shrubby & 1 & & 1 \\
\hline 141 & Schefflera morototoni (Aubl.) Maguire, Steyerm. \& Frodin & Araliaceae & Arboreal & 1 & & 1 \\
\hline 142 & Senefeldera macrophylla Ducke & Euphorbiaceae & Arboreal & 1 & & 1 \\
\hline 143 & Siparuna amazonica Mart. ex A. DC. & Monimiaceae & Arboreal & 1 & & 1 \\
\hline 144 & Smilax schomburgkiana Kunth & Smilacaceae & Liana & & 1 & 1 \\
\hline 145 & Sterculia pruriens (Aubl.) K. Schum. & Sterculiaceae & Arboreal & 1 & & 1 \\
\hline 146 & Swartzia ferruginea & Fabaceae & Arboreal & 1 & & 1 \\
\hline 147 & Tabernaemontana angulate Mart. ex Müll. Arg. & Apocynaceae & Shrubby & 1 & & 1 \\
\hline 148 & Tachigali paniculata Aubl. & Caesalpinaceae & Arboreal & & 1 & 1 \\
\hline
\end{tabular}


APPENDIX.

\begin{tabular}{c|c|c|c|c|c|c}
\hline$\#$ & Species & Family & Life form & Plot C & Plot E & Total \\
\hline 149 & Tovomita brevistaminea Engl. & Clusiaceae & Arboreal & 1 & & 1 \\
\hline 150 & Trichilia quadrijuga Kunth & Meliaceae & Arboreal & 1 & & 1 \\
\hline 151 & Xylopia nitida Dunal & Annonaceae & Arboreal & 1 & & 1 \\
\hline 152 & Zygia racemosa (Ducke) Barneby \& J.W. Grimes & Mimosaceae & Arboreal & 1 & & 1 \\
\hline
\end{tabular}


